\title{
Pemberian Media Photonovela Meningkatkan Pemahaman Isi Informed Consent Pada Pasien Sectio Caesaria di RSIA HST Trenggalek
}

\author{
Dewangga Primananda Susanto*, Harun Al Rasyid, Lukman Hakim \\ * Penulis Korespondensi: dewangga.primananda@yahoo.com \\ * Rumah sakit Ibu dan Anak Harapan Sehat Tentram (HST) Kab. Trenggalek Provinsi Jawa Timur
}

\begin{tabular}{l}
\hline $\boldsymbol{I} \boldsymbol{N D E X I N G}$ \\
\hline Keywords: \\
Medical information; \\
Consent of medical \\
action; Informed consent \\
understanding; \\
Traditional comic strip \\
photonovela;
\end{tabular}

Kata kunci: Informasi medis; persetujuan tindakan medis; pemahaman Informed consent; traditional comic Strip photonovela;

\begin{abstract}
A B S T R A C T
The aim of this research is to know the effect of traditional comic strip photonovela media on the level of informed understanding of patient of Sectio caesarea (SC). This research is a quasi experimental research by dividing the research subjects into two groups namely the treatment group (given photonovela) and control (not given photonovela) each of 30 people in RSIA HST Trenggalek hospital. This study found that group understanding received significantly higher media in terms of explanation of indications, procedures, objectives, alternatives, risks, complications and SC costs compared to patients without photonovela media. There were no significant differences in terms of explanation of action names and SC prognosis in both groups.
\end{abstract}

Penelitian ini bertujuan mengetahui pengaruh pemberian media photonovela jenis traditional comic strip terhadap tingkat pemahaman informed cpnsent pasien Sectio Caesarea (SC). Penelitian ini merupakan penelitian quasi experimental dengan membagi subjek penelitian menjadi dua kelompok yaitu kelompok perlakuan (diberikan media photonovela) dan kontrol (tidak diberikan media photonovela) masing masing sebanyak 30 orang di rawat inap RSIA HST Trenggalek. Penelitian ini menemukan bahwa pemahaman kelompok yang mendapat media lebih tinggi secara bermakna dalam hal penjelasan indikasi, tata cara, tujuan, alternatif lain, resiko, komplikasi dan biaya SC dibandingkan kelompok pasien tanpa media photonovela. Tidak ditemukan perbedaan yang bermakna dalam hal penjelasan nama tindakan dan prognosis SC pada kedua kelompok.

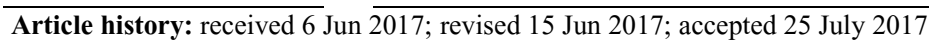

(C) 2017 JMMR. All rights reserved

\section{PENDAHULUAN}

Setiap rumah sakit perlu menjaga mutu dan kualitas pelayanan sesuai dengan standar yang berlaku. Salah satunya adalah menjaga kualitas patient safety dalam penyelenggaraan pelayanan kesehatan. Sejak era akreditasi, patient safety merupakan salah satu indikator penting rumah sakit yang memiliki lingkungan kerja baik, pelayanan yang baik dan jaminan kepuasan pasien. Proses pemberian informed consent di rumah sakit merupakan salah satu indikator jaminan proses patient safety di rumah sakit tersebut telah berjalan dengan baik. Kualitas pemberian informed consent sangat dipengaruhi oleh komunikasi antara dokter dan pasien. Kegagalan komunikasi yang dilakukan oleh tenaga kesehatan berhubungan dengan terjadinya kesalahan medis, hasil pengobatan yang buruk dan meningkatnya aduan malpraktik ${ }^{1}$.

Kualitas pemberian informed consent di rumah sakit seringkali diabaikan dan dirasakan menjadi suatu hal yang penting saat terjadinya tuntutan hukum kepada rumah sakit $^{2}$. Proses pemberian informed consent perlu di evaluasi baik dari sisi direksi / managamen rumah sakit kepada dokter dan antar tenaga medis yang berperan di rumah sakit. Tidak sedikit rumah sakit yang mengabaikan dan memandang sebelah mata dari proses pemberian informed consent oleh dokter penanggung jawab (DPJP). Proses informed consent ini memiliki arti penting pada faktor komunikasi dokter pasien ${ }^{3,4}$. Salah satu permasalahan yang ditemukan di RSIA HST adalah ketidaklengkapan pemberian informed consent sehingga berdampak pada tingkat pemahaman pasien tentang isi informed consent.

Menurut teori komunikasi, media dapat digunkan untuk membantu proses komunikasi selain dari pemberi dan penerima informasi diperlukan suatu pesan agar pesan yang disampaikan pemberi informasi dapat sampai ke penerima dengan baik $^{(5)}$. Media photonovela, dapat digunakan sebagai media penghubung yang komunikasi dokter-pasien. Media photonovela memiliki potensi memudahkan pasien dalam memahami informasi terutama yang memiliki kemampuan rendah dalam memahami informasi medis (health literacy) ${ }^{(6)}$. Photonovela juga diketahui mampu 
meningkatkan daya retensi informasi yang disampaikan dan menggambarkan realitas yang ada ${ }^{(7)}$.

Penelitian ini bertujuan untuk mengetahui pengaruh pemberian media photonovela jenis traditional comic strip, terhadap tingkat peningkatan pemahaman informed consent tindakan SC.

\section{METODE PENELITIAN}

Penelitian ini adalah penelitian quasi experimental research dengan membagi subjek penelitian mejadi dua kelompok, yaitu kelompok perlakuan (diberikan media photonovela) dan kelompok kontrol (tanpa diberikan media photonovela).

Subyek penelitian ini adalah 60 pasien rawat inap di Rumah Sakit Ibu dan Anak (RSIA) Harapan Sehat Tentram (HST) Trenggalek yang terdiri dari 30 sampel kelompok perlakuan dan 30 kelompok kontrol. Subjek penelitian diambil secara random blok yaitu pengambilan secara acak antara kelompok perlakuan dan kontrol. Obyek penelitian ini adalah tingkat pemahaman pasien setelah diberikan media photonovela, dan dibandingkan dengan tanpa diberikan media photonovela. jenis media photonovela yang digunakan pada penelitian ini berasal dari penelitian sebelumnya, yaitu jenis photonovela traditional comic strip. Penilaian evaluasi pemahaman pasien didasarkan pada 9 isi informed consent sesuai permenkes 290 tahun 2008 yang wajib diketahui dan dipahami, yaitu : (1) Indikasi tindakan, (2) Nama / Jenis tindakan (3) Tatacara (4) Tujuan (5) Alternatif lain (6) Resiko (7) Komplikasi (8) Prognosis dan (9) Biaya. Pengukuran pemahaman pasien menggunakan metode teach-back collaborative.

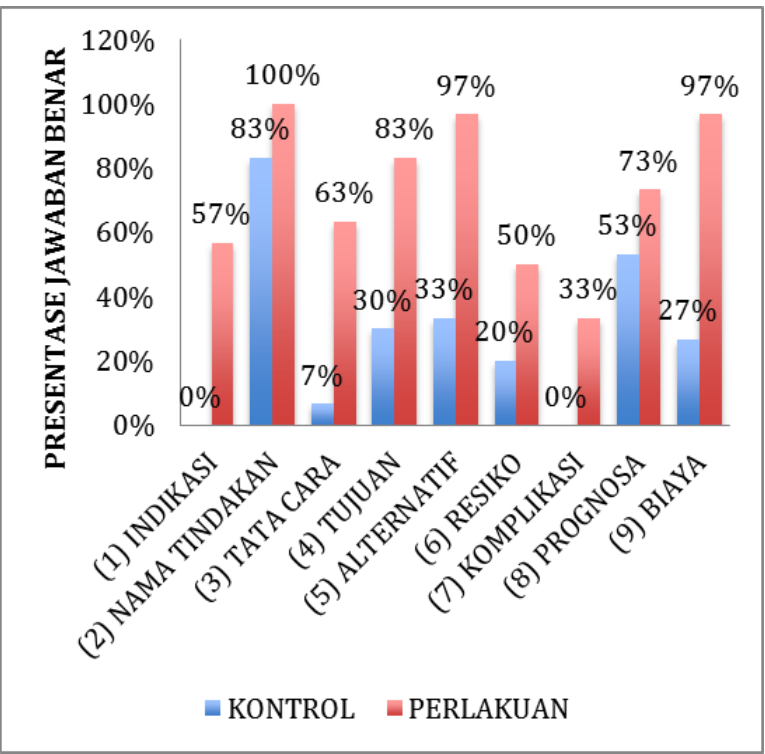

Gambar 1 . Perbedaan presentase jawaban benar 9 Isi informed consent berdasarkan kelompok penelitian yang diukur menggunakan metode Teach-back Collaboratif

Data dianalisis menggunakan independent t-Test untuk membedakan tingkat pemahaman dua kelompok subjek penelitian. Instrumen penelitian menggunakan media photonovela jenis traditional comic strip photonovela yang telah diuji validitas content (CV) pada penelitian sebelumnya.

\section{HASIL DAN PEMBAHASAN}

Karakteristik responden pada penelitian ini, yaitu pasien terbanyak adalah usia 21-25 tahun sebesar $37 \%$ disusul dengan usia 26- 30 tahun yaitu sebanyak 13 orang (30\%). Tingkat pendidikan terakhir pasien yang terbanyak adalah SMA Sederajat sebanyak 25 orang (42\%) disusul jumlah pasien S1 SMP (15\%)

\section{Analisa Deskriptif}

Analisa deksriptif didasarkan pada hasil pengukuran pemahaman pasien baik kelompok perlakuan dan kontrol untuk 9 isi informed consent yang wajib diketahui pasien.

Gambar 1 menunjukkan bahwa dari ke 9 isi informed consent yang diatur dalam permenkes no 290 tahun 2008 terdapat perbedaan yang cukup besar antara kelompok kontrol dan perlakuan. Kelompok perlakuan memiliki pemahaman (persentase jawaban) yang lebih tinggi daripada kelompok kontrol. Perbedaan terbesar terlihat pada indikasi, tata cara, alternatif dan biaya dengan selisih presentase jawaban benar lebih dari 50\%.

\section{Hasil Uji Beda}

Hasil uji Kolmogorov-Smirnov menunjukan bahwa data pemahaman pasien pada dua kelompok terdistribusi normal. Hasil uji homogenitas (levene test) juga menunjukkan kedua kelompok memiliki varians yang homogen

Independent sample t-Test digunakan untuk membandingkan rata-rata presentase jawaban benar antara kelompok perlakuan dan kontrol. Hasil analisis independent t-Test pada total jawaban benar didapatkan nilai $\mathrm{p}<0,001$ yang berarti kelompok yang mendapat media photonovela memiliki nilai rerata lebih tinggi dalam pemahaman seluruh isi informasi di informed consent SC di RSIA HST Trenggalek dibandingkan kelompok yang tidak mendapatkan media. Jika dianalisis lebih detail ada 7 isi 
informed consent yang berbeda secara bermakna pada kedua kelompok yaitu indikasi, tata cara, tujuan, alternative lain, resiko, komplikasi dan biaya. Walaupun demikian, 2 isi informed consent lain yaitu nama tindakan dan prognosis memiliki nilai rerata yang tidak berbeda pada kedua kelompok. (signifikansi $>0.05$ ) (lihat tabel 1).

Tabel 1. Hasil Uji Independent T-test 2 kelompok terhadap 9 Isi Informed consent

\begin{tabular}{lccc}
\hline \multicolumn{1}{c}{ Variabel } & Perlakuan & Kontrol & Signifikansi \\
\hline (1) Indikasi & $0.57 \pm 0.504$ & $0.00 \pm 0.000$ & $<0.001$ \\
(2) Nama tindakan & $1.00 \pm 0.000$ & $0.83 \pm 0.379$ & 0.190 \\
(3)Tatacara & $0.63 \pm 0.490$ & $0.07 \pm 0.254$ & $<0.001$ \\
(4) Tujuan & $0.83 \pm 0.83$ & $0.83 \pm 0.466$ & $<0.001$ \\
(5) Alternatif lain & $0.97 \pm 0.183$ & $0.33 \pm 0.479$ & $<0.001$ \\
(6) Resiko & $0.50 \pm 0.509$ & $0.20 \pm 0.407$ & 0.014 \\
(7) Komplikasi & $0.33 \pm 0.479$ & $0.00 \pm 0.000$ & $<0.001$ \\
(8) Prognosis & $0.73 \pm 0.450$ & $0.53 \pm 0.507$ & 0.112 \\
(9) Biaya & $0.97 \pm 0.183$ & $0.27 \pm 0.450$ & $<0.001$ \\
(10) TOTAL & $6.53 \pm 1.432$ & $2.53 \pm 1.502$ & $<0.001$ \\
\hline
\end{tabular}

\section{Pembahasan}

Dari hasil pengolahan data didapatkan perbedaan yang bermakna pada pemahaman kedua kelompok terkait informed consent tindakan SC. Kelompok yang mendapat media photonovela memiliki pemahaman lebih baik daripada kelompok tanpa pemberian media photonovela. Penelitian ini menunjukkan bahwa media memiliki peran besar dalam menjembatani informasi yang disampaikan oleh pemberi informasi (dokter) kepada penerima informasi sehingga media menjadi alat penting dalam memperbaiki komunikasi dokter pasien. Berdasarkan 9 isi informed consent yang harus disampaikan pada pasien hanya 7 isi informed consent yang berbeda signifikan.

Hal ini menunjukan bahwa pemahaman nama dan prognosis dari tindakan SC tidak dipengruhi oleh media photonovela karena istilah SC mudah ditemukan di media massa manapun, perbincangan keseharian. Selain itu, masyarakat memiliki kepercayaan bahwa hasil tindakan SC banyak yang baik dan oleh dokter penanggung jawab pasien (DPJP) pasti disampaikan penjelasan tentang prognosis tindakan SC pada setiap pasien untuk membesarkan semangat dan sikap kooperatif terhadap dokter.

Berdasarkan kategori kriteria sampel yang diambil apabila dihubungkan dengan nilai yang diperoleh, berdasarkan hasil uji korelasi pearson menunjukan bahwa umur dan pendidikan tidak mempengaruhi hasil peningkatan pemahaman pasien terhadap informed consent tindakan SC. Hal ini menunjukkan bahwa baik dari setiap kelompok umur baik muda maupun tua mampu membaca media ini dengan baik dan dapat menggunakannya untuk meningkatkan pemahaman, begitu pula dengan tingkat pendidikan, SD hingga S1 mampu mengenali dan memahami dengan baik media photonovela yang dibuat dengan baik.

Hasil penelitian ini sesuai dengan temuan Djohani ${ }^{8}$ bahwa media mampu meningkatkan pengetahuan informasi yang ingin disampaikan, dalam hal ini informed consent tindakan SC, dibandingkan hanya mengandalkan penjelasan informed consent oleh dokter penanggungjawab (DPJP) saja. Terbukti nilai yang diperoleh kelompok yang diberikan media lebih tinggi dibandingkan tanpa pemberian media. Hasil serupa juga ditemukan pada penelitian Tiyanto, Binadja (9) menyatakan bahwa poster mampu meningkatkan pemahaman, hasil belajar dan prestasi siswa. Begitu pula dengan penelitian Valle, Yamada ${ }^{10}$ mendapatkan penggunaan media photonovela sangat membantu pasien yang memiliki health literacy rendah untuk memahami proses informasi yang ada pada proses penyuluhan kesehatan kepada orang orang yang memiliki penyakit demensia.

Photonovela sebagai media dapat membantu proses penyampaian informasi yang disampaikan oleh pemberi kepada penerima informasi, selain itu photonovela dalam penelitian ini mempermudah pasien SC dalam memahami informasi tindakan SC dikarenakan beberapa hal, salah satunya photonovela terdiri dari gambar - gambar berbentuk foto yang menjelaskan proses tindakan yang 
akan dijalani oleh pasien. Hal ini membuat pasien tidak hanya mengetahui berdasarkan ucapan lisan dokter ataupun text yang berasal dari lembaran informed consent. Seluruh pen-jelasan dokter mampu diilustrasikan pada media photonovela sehingga pasien mudah dalam membayangkan dan mengerti info yang disampaikan ${ }^{11,12}$.

Hal yang sama menjadi keunggulan media photonovela ini adalah bahasa yang ditampilkan bukanlah bahasa baku (text book) akan tetapi merupakan bahasa percakapan sehari hari yang diperankan oleh dokter dan pasien ilustrasi yang ada pada media. Hal ini sesuai oleh penelitian Mediawati ${ }^{13}$ bahwa media komik dalam hal ini photonovela dapat membantu pasien kembali dalam memvisualisasikan pasien tersebut berada pada posisi gambar ilustrasi di media, sehingga secara tidak langsung pasien akan merasakan keikutsertaan di dalam percakapan. Tentunya hal ini akan semakin membantu pasien dalam memahami informasi tindakan SC.

Hasil penelitian ini diharapkan memberikan masukan bagi manajemen RSIA HST untuk mempertimbangkan penggunaan media dalam membantu meningkatkan pemahaman informed consent pasien dan memperperbaiki cara pemberian informed consent. Hasil penelitian ini menunjukan banyak sekali pasien yang belum paham informed consent tindakan SC yang dilakukan oleh dokter DPJP. Selain itu perbaikan yang perlu dilakukan adalah melakukan evaluasi SOP, formulir dan kebijakan tentang pemberian informed consent SC sehingga memperbaiki proses pemberian informed consent secara keseluruhan

Keterbatasan penelitian ini adalah tidak digunakan media pembanding selain photonovela, untuk membuktikan bahwa media photonovela merupakan media terbaik untuk meningkatkan pemahaman pasien tentang informasi medis di rumah sakit. Selain itu, hasil penelitian ini mungkin hanya relevan untuk pasien yang akan menjalani SC di RSIA HST Trenggalek. Hasil yang berbeda mungkin saja ditemukan di rumah sakit lain yang cara pemberian informed consentnya berbeda.

\section{SIMPULAN}

Berdasarkan hasil penelitian ini dapat disimpulkan bahwa pemberian media photonovela bisa meningkatkan pemahaman pasien terkait informed consent pada pasien SC di RSIA HST Trenggalek, dibandingkan hanya mengandalkan informasi dari dokter penanggungjawab pasien.

RSIA HST perlu mempertimbangkan penggunaan media Photonovela untuk meningkatkan kontrol mutu, mengurangi insiden keselamatan pasien dan meningkatkan patient safety di rumah sakit, Untuk penelitian selanjutnya bisa membandingkan efektifitas photonovela dengan jenis media lainnya, atau mengukur dampak pengunaan media photonovela pada pemberian informed consent tindakan medis selain SC.

\section{DAFTAR PUSTAKA}

1. Aiken, Sermeus, LH, et al. 2012, 'Patient safety, satisfaction, and quality of hospital care: cross sectional surveys of nurses and patients in 12 countries in Europe and the United States', BMJ, vol. 344.

2. Aisyah, S \& Kristiyono, E 2013, Faktor-faktor yang Menyebabkan Ketidaklengkapan Pengisian Lembar Informed Consent Tindakan Bedah Mata di RS. Mata “Dr. YAP”Yogyakarta, Universitas Gadjah Mada.

3. Davis, R, Sevdalis, N \& Vincent, C 2011, 'Patient involvement in patient safety: How willing are patients to participate?', BMJ Quality \& Safety, vol. 20, no. 1, pp. 108-114.

4. Djohani, R, D. J. Widyanto, R. Irfani 2007, 'Panduan untuk fasilitator infomobilisasi, mengembangkan media komunikasi berbasis masyarakat. Jakarta: Tim partnership fore e- prosperity the poor (Pe-PP) Bappenas_UNDP. ', no. Semarang.

5. James, JT 2013, 'A new, evidence-based estimate of patient harms associated with hospital care', Journal of patient safety, vol. 9, no. 3, pp. 122-128.

6. Levtzion-Korach, O, Frankel, A, et al. 2010, 'Integrating incident data from five reporting systems to assess patient safety: making sense of the elephant', The Joint Commission Journal on Quality and Patient Safety, vol. 36, no. 9, pp. 402-AP418.

7. Longtin, Y, Sax, H, et al. 2010, 'Patient participation: current knowledge and applicability to patient safety', Mayo Clinic Proceedings, Elsevier, pp. 53-62.

8. Mediawati, E 2011, 'Pembelajaran akuntansi keuangan melalui media komik untuk meningkatkan prestasi mahasiswa', Jurnal penelitian pendidikan, vol. 12 , no. 1 , pp. $68-76$

9. Novianti, RD \& Syaichudin, M 2010, 'Pengembangan Media Komik Pembelajaran Matematika Untuk Meningkatkan Pemahaman Bentuk Soal Cerita Bab Pecahan Pada Siswa Kelas V SDN Ngembung', Jurnal Teknologi Pendidikan, vol. 10, no. 1, pp. 74-85.

10. Rahayu, A, Murniati, NAN \& Farikhah, I 2013, Kajian Pengembangan Media Pembelajaran IPA 
Menggunakan Fotonovela Berbasis Pendidikan Karakter', lpf 2013.

11. Tiyanto, W, Binadja, A \& Santoso, NB 2014, 'Pengaruh Model Pembelajaran Kumon Berbantuan Media Poster Bervisi Sets Terhadap Pencapaian Kompetensi', Chemistry in Education, vol. 3, no. 1.

12. Utami, D 2011, 'Animasi dalam Pembelajaran', Majalah Ilmiah Pembelajaran, vol. 7, no. 1.

13. Valle, R, Yamada, A-M \& Matiella, AC 2006, 'Fotonovelas: a health literacy tool for educating Latino older adults about dementia', Clinical Gerontologist, vol. 30, no. 1, pp. 71-88. 